\title{
External Morphology of the Immature Stages of Metacuterebra apicalis
}

\author{
Antônio Cesar Rios Leite ${ }^{+}$, Paul Williams \\ Departamento de Parasitologia, Instituto de Ciências Biológicas, Universidade Federal de Minas Gerais, Caixa \\ Postal 486, 31270-901 Belo Horizonte, MG, Brasil
}

The second and third instar larvae, and the pupa of Metacuterebra apicalis (Guérin-Menevilli), are described based on light and scanning electron microscope observations.

Key words: Metacuterebra apicalis - Diptera - Cuterebridae - immature stage - larva - pupa - bot fly

Cuterebrid bot flies are indigenous to the New World, where their larvae cause primary cutaneous myiasis in mammals, including man (Catts 1982). Metacuterebra is restricted to the Neotropical Region.

In nature, the larval stages of $M$. apicalis parasitize rodents (Guimarães 1971, Guimarães et al. 1983, Bossi \& Bergallo 1992, Vieira 1993). The life cycle of this species was described by Leite and Williams (1988).

The morphological characters of the M. apicalis adults were partially described, under light microscope (LM) (Lutz 1917), and redescribed by LM and scanning electron microscope (SEM) observations (Leite \& Williams 1989). Based on LM and SEM studies, the egg and the first instar larva of M. apicalis have been described (Leite \& Williams 1989). To complement our previous studies on the immature stages of $M$. apicalis, the second and third instar larvae, and the pupa are described herein.

\section{MATERIALS AND METHODS}

Three groups, each with six white rats, were infected by introducing two, five or ten first instar larvae of $M$. apicalis into the conjunctiva of the eye (Leite \& Williams 1989). The infected rats were kept individually in wire covered plastic cages and were given a commercial rodent food and $a d$ libitum access to water. On the 9th and 18th days of infection, the rats were killed with ethyl ether and cutaneous lesions were removed. Second and third instar larvae were dissected from surround-

\footnotetext{
This work was partially supported by "Conselho Nacional de Desenvolvimento Científico eTecnológico" of Brazil.

${ }^{+}$Corresponding author. Fax: +55-31-448.1215. E -mail: Rios@mono.icb.ufmg.br

Received 6 May 1997

Accepted 17 July 1997
}

ing tissues. Some rodents were maintained until third instar larvae emerged from their hosts; these free-larvae were maintained until survivors transformed into pupae. Material destined for LM studies were fixed in Dietrich/San Jean fluid for $2 \mathrm{hr}$ and then stored in $70 \%$ ethanol until examination. Material for SEM examination were killed in hot water $\left(70^{\circ} \mathrm{C}\right)$, fixed in $70 \%$ ethanol, dehydrated in a ethanol series, submitted to $\mathrm{CO}_{2}$ critical point drying and spattered with gold. At least eight specimens of each immature stage were studied.

\section{RESULTS}

Second instar larva - On the ninth day of infection, the second instar larva (Fig. 1) is subcylindrical in shape, pale in colour, and measures $5.58-7 \mathrm{~mm}$ in length and $1.24-1.79 \mathrm{~mm}$ wide at the level of the thorax. The pseudocephalum bears tuberiform antennae. The first thoracic segment (Fig. 2) is surrounded anteriorly by small curved thorn-like spines, each with a backwardly directed simple tip. Occasionally, bare patches were seen in the anterior region. The second and the third thoracic segments (Fig. 2) are anteriorly encircled by backwardly directed thornlike spines with simple tips; a few spines with twoand three-pointed tips were seen on the third thoracic segment. From the first to the fifth abdominal segments (Fig. 3), anterior spines are similar to those on the third thoracic segment. The sixth abdominal segment bears anterior thorn-like spines (Fig. 4) with backwardly directed simple tips. On the seventh abdominal segment, there are a few anterior spines, all implanted on the ventral surface (Fig. 4). Posteriorly, the second to the eighth abdominal segments have spines with forwardly directed simple tips. Usually the posterior spines are larger than the anterior ones. The second abdominal segment has fewer spines than the following segments. Spines with two, three or multiple tips ( Figs 5, 6) occur in the anterior region of the second to the sixth abdominal segments and in 
the posterior margin from the third to the fifth abdominal segments. The opening of the anterior spiracle (Fig. 7) is in the form of an invaginated, transverse slit, and is situated lateral to the posterior margin of the second segment. The eighth abdominal segment is unarmed anteriorly.
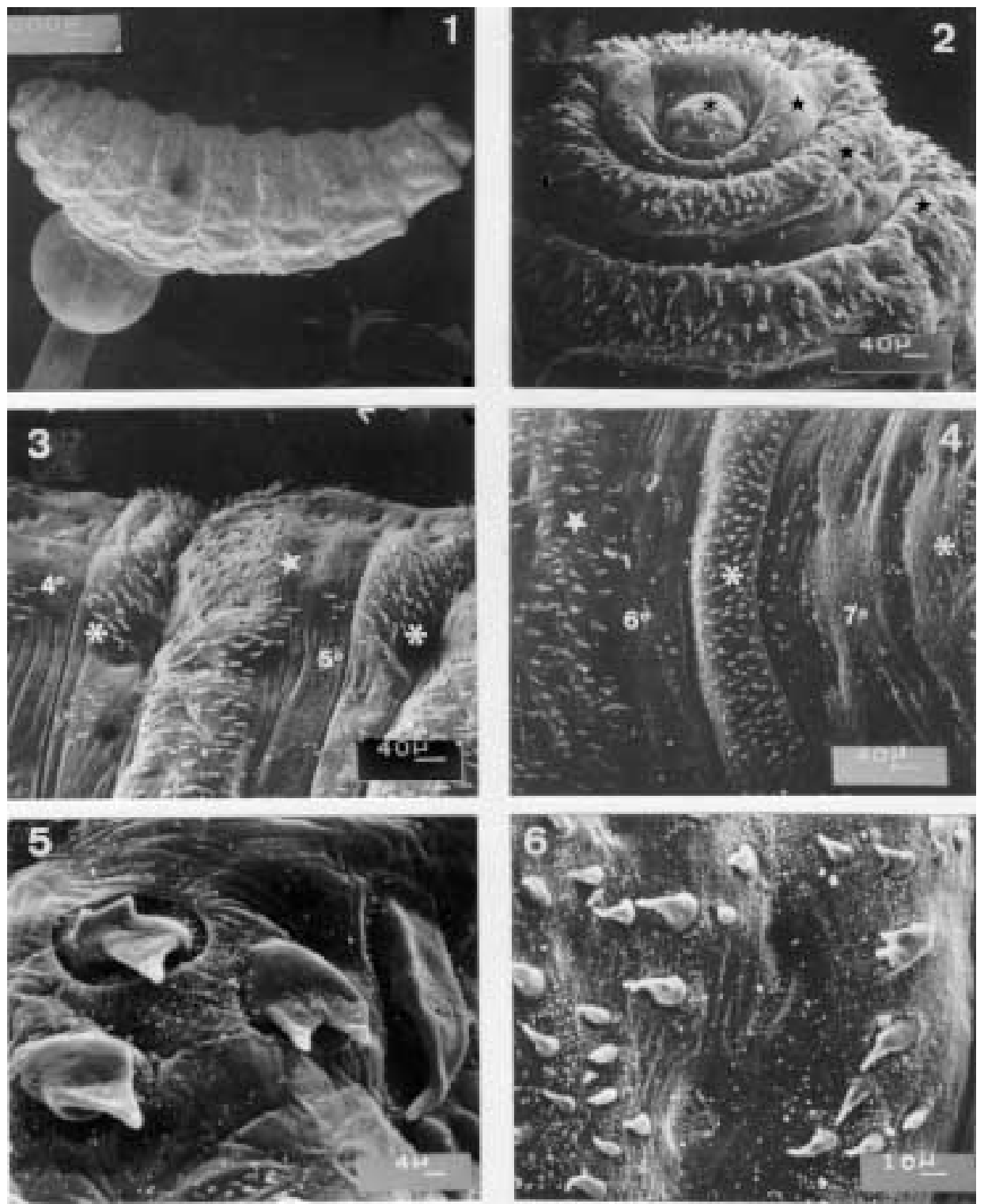

Scanning electron micrographs of the second instar larva of Metacuterebra apicalis collected on the ninth day post-infection of rats. Fig. 1: whole body in lateral view. Fig. 2: anterior end showing the pseudocephalum (asterisk), and the three thoracic segments (star) in ventral view. Fig. 3: anterior (star) and posterior (asterisk) spines of the fourth $\left(4^{\circ}\right)$ and fifth $\left(5^{\circ}\right)$ abdominal segments in ventral view. Fig. 4: anterior (star) and posterior (asterisk) spines of the sixth $\left(6^{\circ}\right)$ and seventh $\left(7^{\circ}\right)$ abdominal segments in ventral view. Fig. 5: anterior spines of the fourth abdominal segment showing spines with two and three tips (arrow). Fig. 6: anterior spine of the sixth abdominal segment. Bar $=\mu \mathrm{m}$. 
plates. The anus is surrounded by two anal tubercles, each bearing small plates.

The cephalopharyngeal skeleton (Figs 11, 12) is dark-brown from the anterior end to the central region, and colourless posteriorly. The maxillae are smooth, wide at the base, ventrally curved and distally pointed. The dental sclerite occupies a lateral and subterminal position on the maxilla. The hypopharyngeal and tentopharyngeal sclerite are united. The two dorsal cornua are separated distally and united basally to ventral cornua, which are fused with the pharynx on each side. The pos-
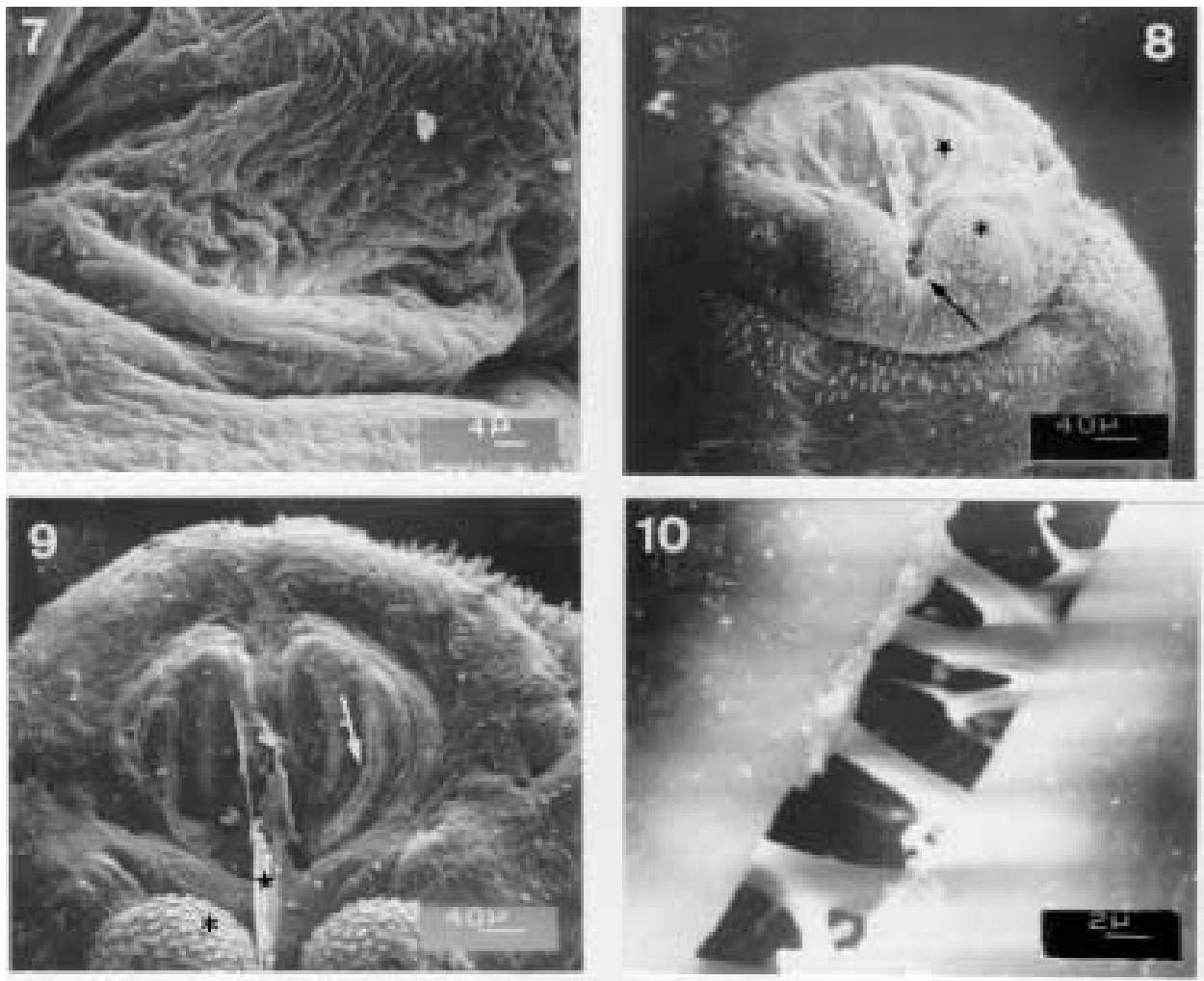

11
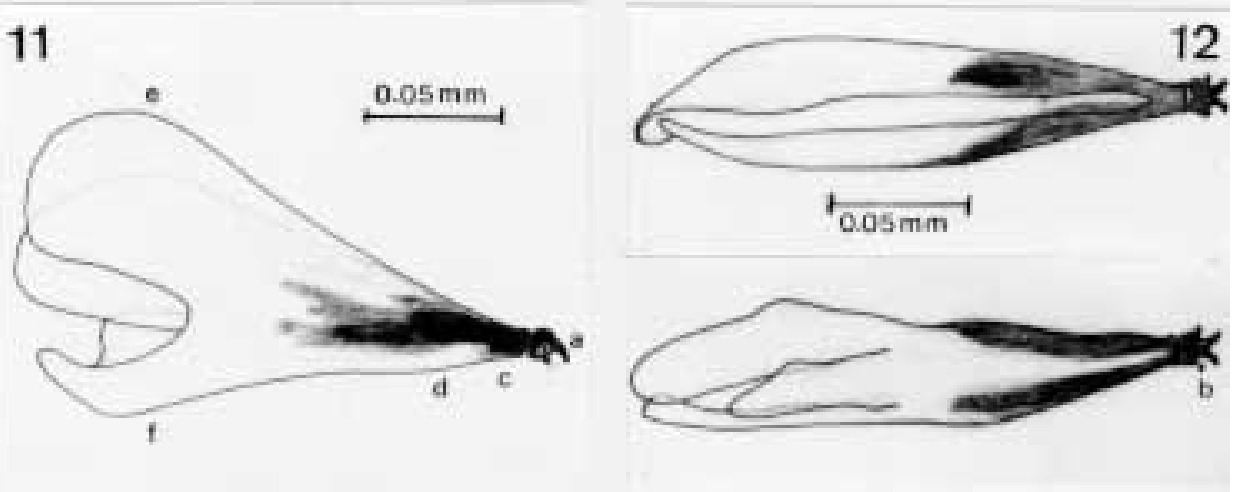

Scanning electron micrographs and camera lucida drawings of the second instar larva of Metacuterebra apicalis collected on the ninth day post-infection of rats. Fig. 7: the opening of the anterior spiracle. Fig. 8: posterior end showing the spiracular plate (star), anal tubercle (asterisk) and anus (arrow) in ventro-terminal view. Fig. 9: terminal end showing the spiracular opening (arrow), ecdisial scar (star) and anal tubercle (asterisk) in terminal view. Fig. 10: spiracular trabeculae. Fig. 11: cephalopharyngeal skeleton in lateral view. Fig. 12: idem, in dorsal (above) and ventral (below) views. Abbreviations: a: maxilla, b: dentate sclerite, c: hypophyngeal sclerite, $\mathrm{d}$ : tentopharyngeal sclerite, e: dorsal cornu, f: ventral cornu. $\mathrm{Bar}=\mu \mathrm{m}$. 
terior margins of the dorsal and ventral cornua are markedly grooved.

Third instar larva - On the 18th-day of infection, the larvae are in the third instar. This larva has a cylindrical shape, is pale in colour, measures $11.2-18.88 \mathrm{~mm}$ in length and is $4.48-11.2 \mathrm{~mm}$ wide (at the level of the thorax). The pseudo- cephalum bears two tuberculate antennae, each bearing two small sensilla, and a few plates with smooth margins. The maxillae (Figs 13-15), are smooth, broad at the base, ventrally curved and sharpened distally. The three thoracic segments are each covered anteriorly by plates, which have smooth or serrated margins (Fig. 16). On each seg-
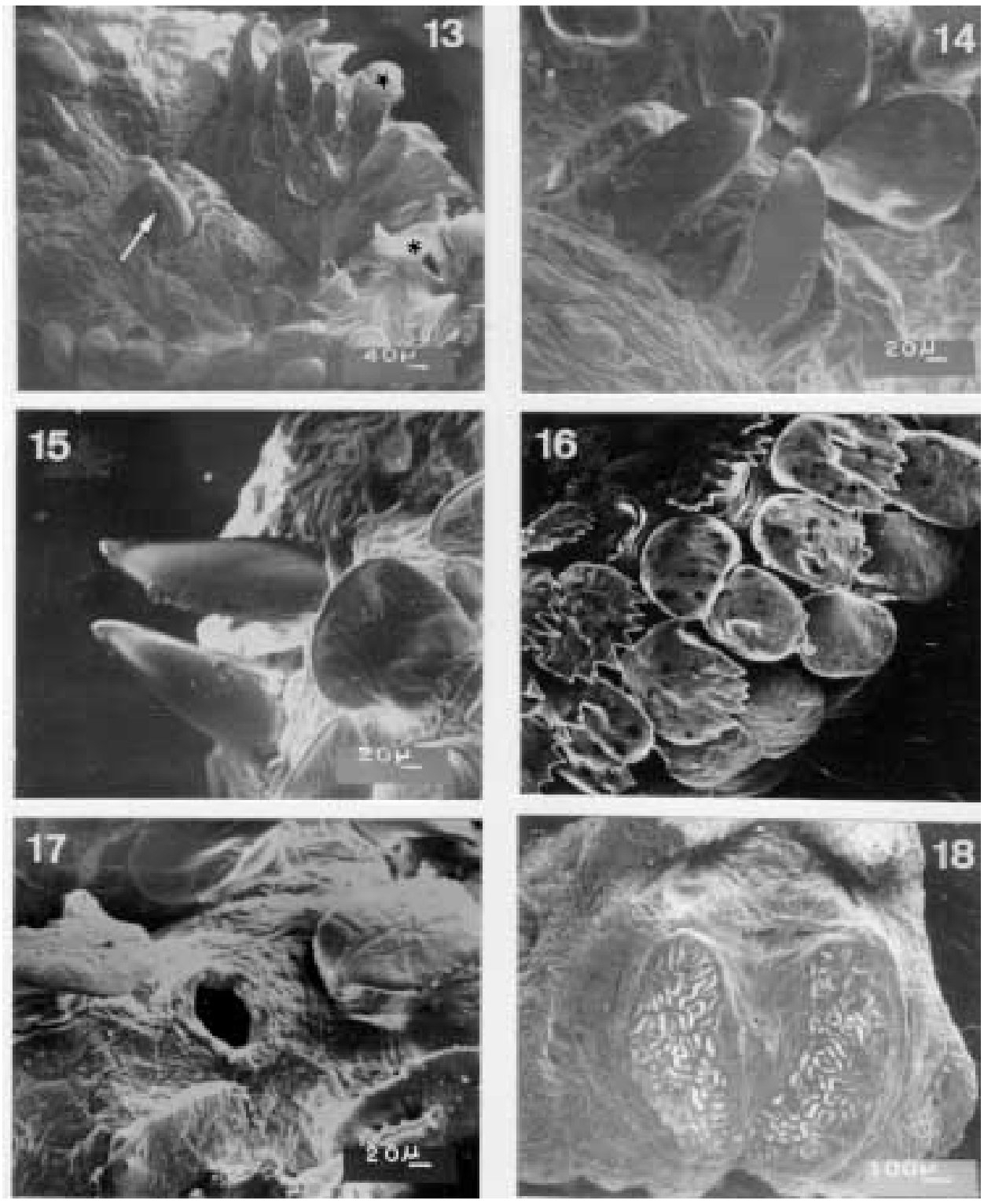

Scanning electron micrographs of the third instar larvae of Metacuterebra apicalis collected on the 18th day post-infection of rats. Fig. 13: anterior end showing the maxillae (arrow), plate spines (star), and anterior spiracular opening (asterisk) in ventro-lateral view. Fig. 14: maxillae in ventral view. Fig. 15: idem, in dorsal view. Fig. 16: plate spines on the thoracic segment. Fig. 17: anterior spiracular opening. Fig. 18: posterior spiracular plates showing the intertwined serpentine slits. Bar $=\mu \mathrm{m}$. 
ment, the plates are imbricated and directed posteriorly in the anterior half and, thereafter, are forwardly directed. The circular spiracular aperture (Fig. 17) is well defined.

There are several sensilla on thoracic segments. The first seven abdominal segments have plates and sensilla, with distributions similar to those on the thorax. The eighth abdominal segment, without plates, bears light-brown thorn-like spines, which have one, two or three backwardly directed tips. Each spiracular plate is bright in colour and bears three interrupted sectors of intertwined serpentine slits (Fig. 18). Strong trabeculae are visible through the spiracular slits. The anal tubercles have small plate and the anus is anteriorly and posteriorly bordered by thorn-like spines.

Immediately after emerging from the host, the third instar larvae is black-brown in colour, and measures $23.94-35.25 \mathrm{~mm}$ in length by $11.7-13.43$ $\mathrm{mm}$ in width. The pseudocephalum (Fig. 19) is like that of the 18-day old parasitic larvae. On the tegument of the three thoracic segments there are plates, with smooth anterior edge, up to the me- dian region; following, posteriorly, by plates with serrated anterior edge. The anterior spiracular opening has white respiratory papillae (Fig. 20). The first six abdominal segments bear plates distributed like those of the thoracic segments. The seventh abdominal segment is covered over by plates with smooth margins, whereas the eighth abdominal segment has thorn-like spines with one to three tips. The median region of the thoracic and abdominal segments have a circlet of cylindrically shaped sensilla (Fig. 21). The surface of the posterior end is similar to that of 18-day parasitic larva, such as the spiracular slits (Fig. 22).

The cephalopharyngeal skeleton (Figs 23-26) of the emerged larva bears dark-brown to black maxillae, which are smooth, apically sharpened and broad basally. The dark-brown hypopharynx is fused anteriorly to the maxillae and posteriorly to the tentopharynx. The latter has a dark-brown median region, with the rest colourless. The expanded and colourless dorsal cornua, fused with colourless ventral cornua, shows a median narrow groove. The ventral cornua becomes tube-like and merges
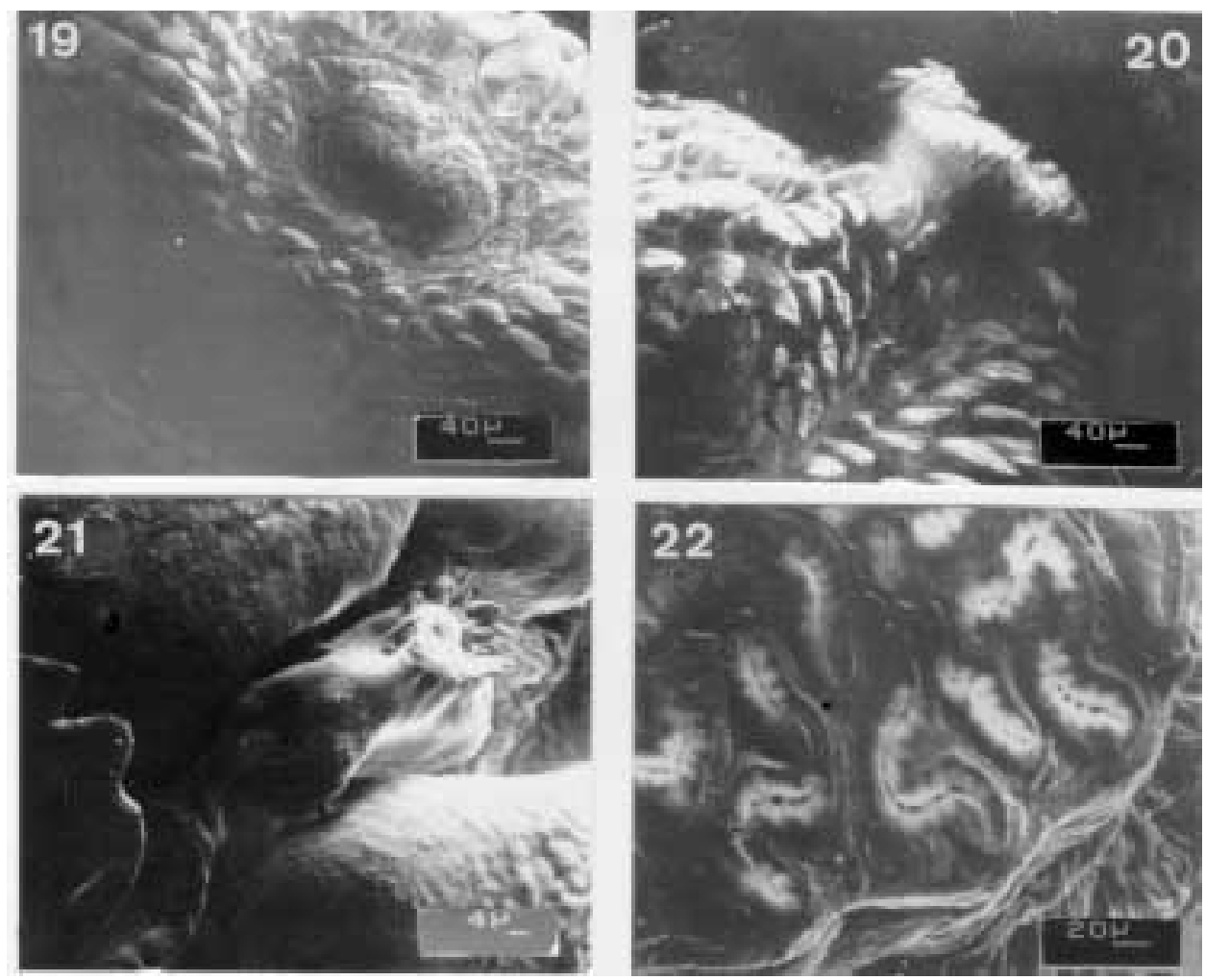

Scanning electron micrographs of the emerged third instar larva of Metacuterebra apicalis. Fig. 19: pseudocephalum in ventral view. Fig. 20: prominent anterior spiracle in ventral view. Fig. 21: cuticular sensilla. Fig. 22: posterior spiracular slits. 

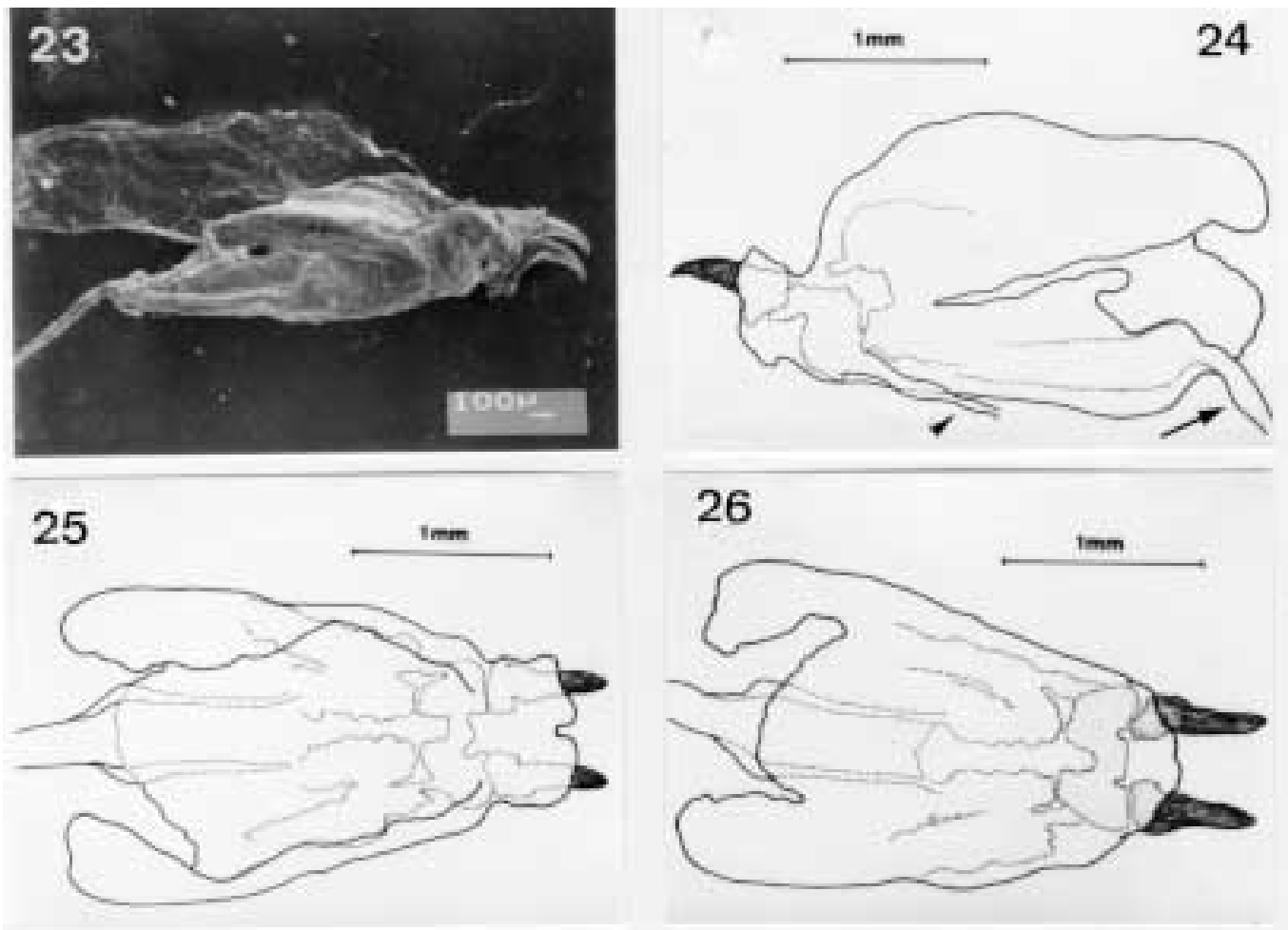

Scanning electron micrographs of the emerged third instar larva of Metacuterebra apicalis. Fig. 23: cephalopharyngeal skeleton in lateral view. Bar $=\mu \mathrm{m}$. Fig. 24: idem, camera lucida drawing showing the salivary duct (arrow head) and oesophagum (arrow) in lateral view. Fig. 25: idem, in dorsal view. Fig. 26: idem, in ventral view.

with the pharynx and, then, with the oesophagus. A small tube connects with the cephapharyngeal skeleton, anterior-laterally, is probably a salivary duct .

Pupa - The dark pupa (Fig. 27) is $23.13-27.28$ $\mathrm{mm}$ in length and $9.83-13.57 \mathrm{~mm}$ wide, at the level of the base of the operculum. Anteriorly, the pseudocephalum and the thoracic segments are retracted posteriorly. The seventh and eighth abdominal segments are also retracted. The integument is covered with plates (Figs 28-30). Each triangular operculum has the spiracular opening situated latero-apically (Fig. 31). The Fig. 32 shows the spiracular papillae.

\section{DISCUSSION}

Although more than 70 species of Cuterebrids have been described (Guimarães 1967, 1984, Catts 1982, Sabrosky 1986), little is known about their immature stages.

When observed by light microscopy, the body of the second instar larva of $M$. apicalis is similar to those of Cuterebra species (Knipling \& Brody 1940, Penner 1958, Dalmat 1942, Bennett 1955,
Haas \& Dicke 1958, Capelle 1970, Baird \& Graham 1973), but differs from that of Dermatobia hominis (Moya Borja 1966) in general body shape and in the arrangement of the spines. The cephalonpharyngeal skeleton of $M$. apicalis is like those of C. buccata (Knipling \& Brody 1940) and of the probable M. flaviventris (Disney 1969), except the $\mathrm{T}$ form of the hypopharyngeal sclerite and the flat dorsal cornu observed in C. buccata. The maxillae with a very sharp tip in C. buccata, M. flaviventris, and C. tenebrosa (Baird \& Graham 1973), and thick tip in C. peromysci (Dalmat 1942) were not observed in M. apicalis. Spines with double tips seen in M. apicalis have been recorded only in second instar larva of C. tenebrosa (Baird \& Graham 1973).

The third instar larva of $M$. apicalis is unlike the third instar larva of $D$. hominis, by the same differences mentioned for second instar larva and by the presence of three slight curved slits in posterior spiracular plates. The external morphology of the third instar larva of M. apicalis is like that of M. schalzi (Henriksen 1942), M. chiquibulensis and M. flaviventris (Disney 1969), and of rodent Cute- 

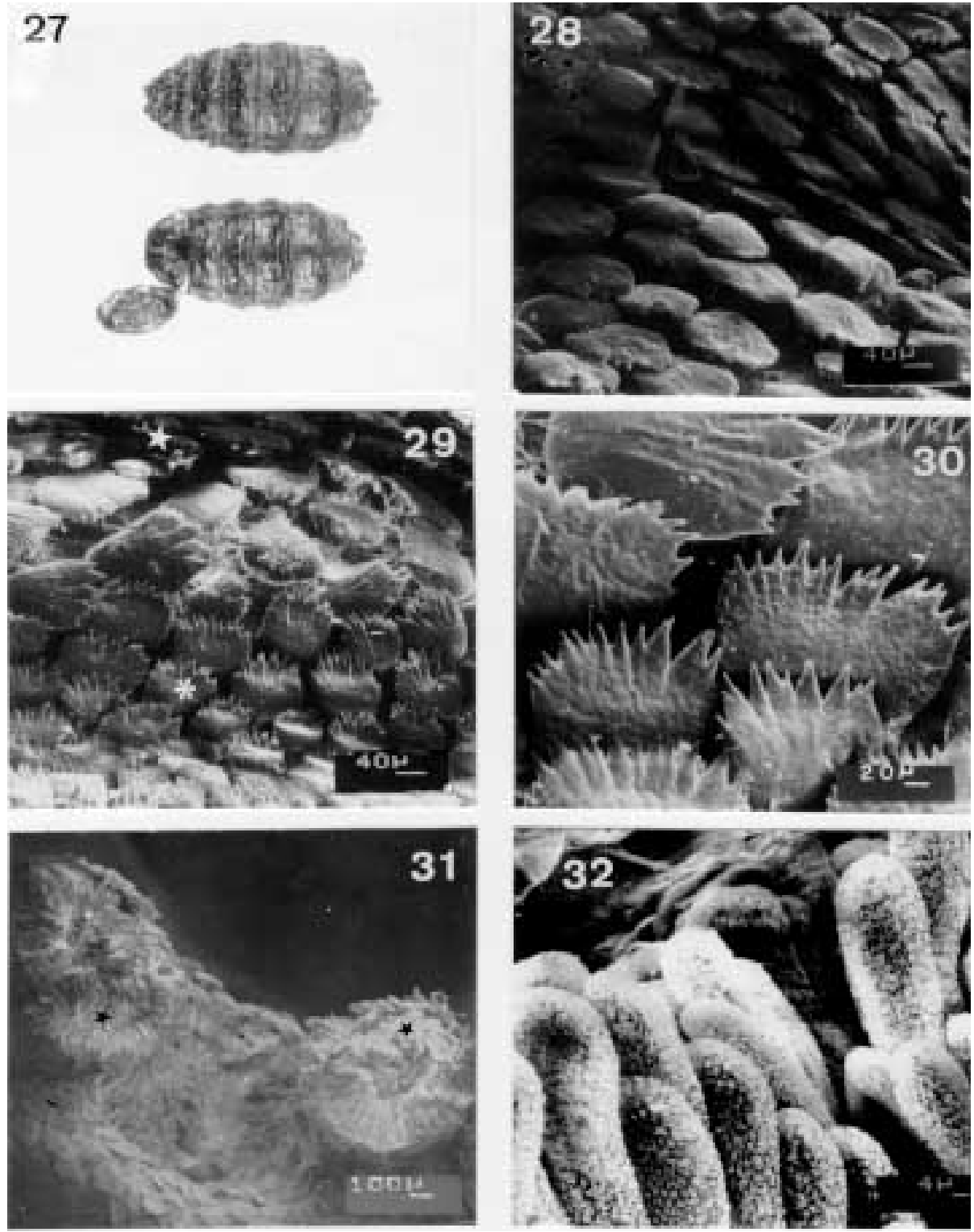

Light and scanning electron micrographs of the pupa of Metacuterebra apicalis. Fig. 27: pupa (above) and puparium (below) in dorsal view; x1.3. Fig. 28: anterior plate on the third abdominal segment. Fig. 29: anterior (arrow) and posterior (arrow head) plate on the fourth abdominal segment. Fig. 30: posterior plate spines on the fourth abdominal segment. Fig. 31: anterior spiracle (arrow). Fig. 32: respiratory papilla. Bar $=\mu \mathrm{m}$.

rebra. Rabbit Cuterebra have a single-pointed spine on cuticular plates whereas Cuterebra from rodents show multiple-pointed spines on plates (Baird 1971). The mature bot of wild primates, Allouattamyia baeri (Shannon \& Greene 1926, Zeledon et al. 1957), has a typical form of
Metacuterebra with dentate plates and spiracular plates with intertwined serpentine slits, but shows distinctions, such as: pronunciate furrow among the segments, as grenade-like, and plates with single and double tips. The strong maxillae in $C$. peromysci (Dalmat 1942) and A. baeri (Zeledon 
et al. 1957), and the very sharp maxillae in $C$. buccata and C. cuniculi (Knipling \& Brody 1940), C. thomomuris (Jellison 1949), M. flaviventris (Disney 1969) and C. polita (Capelle 1970) are not observed in M. apicalis. The sensilla on M. apicalis may be like those described as papillae in $C$. tenebrosa larva (Baird \& Graham 1973). M. apicalis, with $25 \mathrm{~mm}$ long, emerged from Oryzomys flavescens (Henriksen 1942) and $R$. norvegicus (Led et al. 1976) are between the parameters described in the present work. Similar dimensions, comparable with $M$. apicalis, were recorded in C. buccata (Knipling \& Broady 1940), C. latifrons (Catts 1967), and C. tenebrosa (Baird 1975). The emerged larvae of $C$. americana (Capelle 1970) is smaller and of C. cuniculi (Haas \& Dicke 1958) is larger than M. apicalis.

Like other described pupae of Cuterebra [C. peromysci (Dalmat 1942) and C. tenebrosa (Baird \& Graham 1973)], the M. apicalis pupa exhibits ten apparent segments, which preserve the cuticular plates of the third instar larva, and whose operculum occupies the five first tergites. The pupa of M. apicalis and Cuterebra have contractile sternites instead of contractile tergites reported in $\mathrm{Hy}$ poderma bovis (McLintock 1964). Puparium size of $M$. apicalis is similar to those of C. lepusculi (Townsend 1897) and C. tenebrosa (Baird \& Graham 1973), smaller than C. cuniculi (Haas \& Dicke 1958), and larger than C. peromycis (Dalmat 1942).

\section{ACKNOWLEDGEMENTS}

To the "Centro de Microscopia Eletrônica, ICBUFMG" for the use of the scanning electron microscope.

\section{REFERENCES}

Baird CR 1971. Development of Cuterebra jellisoni (Diptera: Cuterebridae) in six species of rabbits and rodents. J Med Entomol 8: 615-622.

Baird CR 1975. Larval development of the rodent botfly, Cuterebra tenebrosa, in bushy-tailed wood rats and its relationship to pupal diapause. Can J Zool 53:1788-1798.

Baird CR, Graham CL 1973. Cuterebra tenebrosa: Description of immature stages and a redescription of the adult (Diptera: Cuterebridae). Can Entomol 105: 1281-1293.

Bennett GF 1955. Studies on Cuterebra emasculator Fitch 1856 (Diptera: Cuterebridae) and a discussion of the status of the genus Cephenemyia Ltr 1818. Can J Zool 33: 75-98.

Bossi DEP, Bergallo HG 1992. Parasitism by cuterebrid botflies (Metacuterebra apicalis) in Oryzomys nitidus (Rodentia: Cricetidae) and Metachirus nudicaudatus (Marsupialia: Didelphidae) in a southeastern Brazilian rain forest. J Parasitol 78: 142145.

Capelle KJ 1970. Studies on the life history and development of Cuterebra polita (Diptera: Cuterebridae) in four species of rodents. J Med Entomol 7: 320-327.

Catts EP 1967. Biology of a California rodent bot fly Cuterebra latifrons Coquillett (Diptera: Cuterebridae). J Med Entomol 4: 87-101.

Catts EP 1982. Biology of New World bot flies: Cuterebridae. Ann Rev Entomol 27: 313-338.

Dalmat HT 1942. A new parasitic fly (Cuterebridae) from the northern white-footed mouse. J NY Entomol Soc 50: 45-59.

Disney RHL 1969. Notes on rodent warble-flies from British Honduras including the description of a new species of Cuterebra Clark (Dipt., Cuterebridae). Entomol Mon Mag 104: 189-197.

Guimarães JH 1967. A catalogue of the Diptera of the Americas south of the United States, family Cuterebridae. Dep Zool Sec Agric São Paulo 105: 1-11.

Guimarães JH 1971. Notes on the hosts of neotropical Cuterebrini (Diptera: Cuterebridae), with new records from Brazil. Pap Avulsos Zool 25: 89-94.

Guimarães JH 1984. New genera and species of neotropical Cuterebridae (Diptera: Cyclorrhapha). Rev Bras Entomol 28: 23-37.

Guimarães JH, Papavero N, Prado AP 1983. As miíases na Região Neotropical (Identificação, Biologia, Bibliografia). Rev Bras Zool 1: 239-416.

Haas GE, Dicke RJ 1958. On Cuterebra horripilum Clark (Diptera: Cuterebridae) parasitizing cottontail rabbits in Wisconsin. J Parasitol 44: 527-540.

Henriksen KL 1942. A note upon two South American species of warble-flies (Cuterebra apicalis Guér. and Schmalzi Lutz), parasites of rodents. Entomol Med 22: 284-289.

Jellison WL 1949. Cuterebra thomomuris sp. nov., a warble from the pocket gopher, Thomomys talpoides (Rodentia: Geomyidae). J Parasitol 35: 482-486.

Knipling EF, Brody AL 1940. Some taxonomic characters of cuterebrine (Diptera) larvae, with larval descriptions of two species from Georgia. J Parasitol 26: 33-43.

Led JE , Colacelli A , Boero JJ , Colombo EG 1976. Parasitismo por Cuterebra apicalis, Guerin 1829, (Insecta - Diptera - Cuteribridae) en rata (Rattus norvegicus). Analecta Vet 6-7-8: 35-37

Leite ACR, Williams P 1988. The life cycle of Metacuterebra apicalis (Diptera: Cuterebridae). Mem Inst Oswaldo Cruz 83: 485-491.

Leite ACR, Williams P 1989. Morphological observations on the egg and first instar larva of Metacuterebra apicalis (Diptera: Cuterebridae). Mem Inst Oswaldo Cruz 84: 123-130.

Lutz A 1917. Contribuições ao conhecimento dos Oestrideos brasileiros. Mem Inst Oswaldo Cruz 9: 94-113.

McLintock J 1964. Puparium formation in Diptera. $\mathrm{Na}$ ture 201: 1245.

Moya Borja GE 1966. Estudios sobre la biología,morfología y esterilización del torsalo, Dermatobia hominis (L., Jr.). MSc Thesis. Turrialba Instituto Interamericano de Ciencias Agrícolas de 1 OEA Centro de Enseñanza Investigación, 63 pp.

Penner LR 1958. Concerning a rabbit cuterebrid, the larvae of which may penetrate the human skin (Diptera: 
Cuterebridae). J Kans Entomol Soc 31: 67-71.

Sabrosky CW 1986. North American species of Cuterebra, the rabbit and rodent bot flies (Diptera: Cuterebridae), Vol 11. Thomas Say Foundation. Entomological Society of America, College Park, Maryland, $240 \mathrm{pp}$.

Shannon RC, Greene CT 1926. A bot-fly parasitic in monkeys. Zoopathologica 1: 285-290.

Townsend CHT 1897. Description of the bot-fly of the cotton-tail rabbit in New Mexico, Cuterebra lepusculi n. sp. Psyche 8: 8-9.

Vieira EM 1993. Occurrence and prevalence of bot flies, Metacuterebra apicalis (Diptera:Cuterebridae), in rodents of cerrado from central Brazil. J Parasitol 79: 792-795.

Zeledón R, Jiménez OQ, Brenes RRM 1957. Cuterebra baeri Shannon y Greene, 1926 en el mono aullador de Costa Rica. Rev Biol Trop 5: 129-134. 